weeks ago, the Bank of England saved from bankruptcy a bank that should have been allowed to go to the wall. The same government is doing everything it can to encourage the growth of a few high-technology sectors without recognizing that they are unlikely to succeed unless there is a climate in which intermediate technology can also prosper. But as if to show its evenhandedness, the government also goes to great trouble to ensure that its chosen sunrise industries fall flat on their faces needlessly. Thus it is that the two most experienced operators, Rediffusion and Visionhire, last week pulled out of the nascent cable industry, the brave new industry of 1982 , because the terms of operating licences have been made unduly onerous.

The consequences of all this are evident. The free market in manufactured goods and value-added services is both hamstrung and feather-bedded. Why should the labour market be singled out for exceptional efficiency, with all the political trouble (and inequity) that would cause? But the civil service, acting as proxy entrepreneur, makes mistakes whose cost is never counted, but which can be measured by the collective impoverishment. But these are the circumstances in which, in a mobile world, people who think they can better themselves elsewhere are up and off. The cost to Britain of the shiploads of those who have left for good, convinced that Britain has nothing much to offer, is incalculable.

It is in the circumstances no wonder that the word has got about that Britain is not serious about its talk of joining the modern world. What sense can it make that a government seeking to sponsor a new industry should cripple it with artificial conditions that prevent it from being viable? Or that it should delegate decisions such as whether there should be another nuclear power station in Britain, not to the nationalized industry that would build and operate the plant, but to a one-man tribunal (with two advisers) sitting daily in Suffolk for the past two years? Would it not be better that the government should tackle the problems that nobody else has the power to tackle, such as the reform of public education? And should it not from time to time make speeches that give some hint that it is not entirely overwhelmed by the despondency about the future which, for want of evidence to the contrary, must be the general conviction.

\section{Argument too formal}

\section{The US National Academy has a new journal}

on public policy, which deserves to succeed.

AFTER more than a decade of introspection, the National Academy of Sciences in Washington has published the first issue of its journal concerned with the general implications of its members' professional work. Issues in Science and Technology is as handsome a publication as would be expected, given both the sources (the National Academy of Engineering and the Institute of Medicine are also partners in the venture) but also the ambition - to provide a regular (quarterly) commentary on important issues and related public policies that will compare in influence with publications such as Foreign Affairs. The Fall 1984 issue deals with some of the issues certain to be recurrent themes in the years ahead - ballistic missile defence, the cost of health care and the regulatory impediments to the application of technical innovation (specifically, the introduction of air bags as safety devices in impacting automobiles). At $\$ 6.00$, the first issue is a good read, or at least an interesting one.

What will follow next is, naturally, not necessarily determined by this first advertisement of what the academies have in mind. Next time, for example, there will be no need to reprint the article by Daniel Yankelovich, the social pollster, retailing a simple account of why public disenchantment with science and technology has been growing since the $1960 \mathrm{~s}$. (The influence of articles on this same theme has not, unfortunately, been recorded.) Arms control is, however, certain to be a recurrent theme, and the first issue includes a pair of opposing articles, by Dr George A. Keyworth and Dr Sydney Drell, on star wars and related matters. Most people will find this a valuable summary of influential opinions on the subject.

So haven't the academics been brave, venturing so far from academic ways? That is what the blurbs suggest. The trouble is that neatly counterbalanced articles are less a way of helping to form opinion than to inform it. If Issues is to win the influence it seeks, it will at some stage have to climb down off this fence, not so as to be partisan but to avoid the appearance of seeking equal time within every pair of covers! And it will have to carry regular book reviews, not just thumbnail sketches of them. But the enterprise is brave; we shall all be better off it it succeeds.

\section{Truth will out (if late)}

\section{The departure from the United States of a once-} German rocket engineer is a chilling lesson.

THE surprising announcement last week that Arthur Rudolph, who designed the Saturn V rocket, had left the United States and given up his US citizenship to avoid deportation as a Nazi war criminal should be enough to convince the most dedicated pragmatists of the moral contradictions in the recruitment of Nazi scientists at the close of the Second World War. More than a hundred Nazi scientists and technicians were then whisked to the United States in an effort to exploit Germany's commanding expertise in rocketry at that time - and, perhaps of greater importance to the US military commanders who directed the operation, to prevent Nazi experts from falling into the hands of the Soviets, as many nonetheless did.

The United States was plainly eager to overlook the obvious fact that these scientists had, with no apparent moral qualms, fully supported and enthusiastically worked for the Nazi regime; scientists are always called upon to build weapons for their country during wartime, the easy rationalization went, and these scientists just happened to be in the wrong country. It was not their fault; they were just following orders. And, mass memory being what it is, few in the United States seem to have been genuinely troubled that their space programme was partly run by the men who built the $\mathrm{V}-2$. A rare dissent was registered in the 1960 s by satirical songwriter Tom Lehrer, who summed up the amorality of the rocket scientists with his biting irony, ascribing to Wernher von Braun the opinion that where the rockets came down was "not my department".

The Rudolph case offers a reminder that really should not be needed that Nazi Germany was not just another country at war. Rudolph's job as director for production of the V-2 made him not only a collaborator with the German war effort, but with the most enormous of the Nazi horrors as well. The workers in the underground factory that produced the V-2 were slave labourers and concentration camp inmates. Of the 60,000 prisoners who passed through the Dora-Nordhausen concentration camp adjacent to the factory, one-third died. The Justice Department now says that Rudolph "participated in the persecution" of these labourers, who were worked 12 hours a day, starved, forced to sleep on bare rock in the tunnels and beaten.

The United States Government did not require 40 years to discover these facts. Rudolph was interrogated by US Army investigators in 1947, on that occasion giving contradictory answers to questions about treatment of prisoners, ultimately acknowledging that he had witnessed the execution of 12 prisoners accused of sabotage. But only the establishment in 1979 of a special office within the Justice Department, charged with investigating suspected war criminals in the United States, seems to have led to the recent action against Rudolph.

There is another reminder in this story. As much as researchers (and, it seems particularly, university administrators) like to maintain that science is not to be judged by its "end use", there are exceptions. Scientific research is a neutral, amoral enterprise only in a free society, one with a democracy capable of exercising social judgement over the propriety of end uses. In the absence of such social judgement, scientists have an obligation to exercise a personal moral judgement, to think through the consequences of their actions. 